\title{
Minangkabau -i: A locative, transitivizing, iterative, adversative suffix
}

\author{
Daniel Brodkin \& Catherine Fortin*
}

\begin{abstract}
Minangkabau, a Malayo-Polynesian (Austronesian) language of Sumatra, displays a small but complicated system of verbal morphology resembling those of its near, better-described relatives Indonesian and Malay. In these languages, the verbal morphemes are multifunctional, and fully characterizing their meanings and uses has proven challenging. We present our findings on $-i$, which previous literature frequently characterizes as a type of applicative. We identify four distinct productive functions of $-i$, not all applicative: adding a locative object, transitivizing non-verbal roots, adding iterative/intensive aspects, and imputing adversative readings. Adversative $-i$ has not previously been identified in the literature, and is unattested in Indonesian.
\end{abstract}

Keywords. Minangkabau; Indonesian; Malay; Austronesian; morphology; applicative; valency; locative; adversative

1. Introduction. Austronesian languages are well-known for having complex systems of voiceand valency- adjusting verbal morphology. Many of the most conservative languages in the family feature "symmetrical" voice systems, where verbs may agree with agents, patients, locatives, and benefactors- and consequently, many of these languages must feature a complex set of valency-increasing morphology to license these additional verbal arguments.

Indonesian and Malay, two closely-related languages, are well-known for having compact, yet complicated verbal systems of this type. Within the Malayic subfamily, most languages contain a set of voice-adjusting prefixes, coupled with a smaller group of valency-adjusting suffixes. Together, these affixes combine in intricate ways to form a morphologically complex verbal system similar to that described above.

Typically, these voice systems feature high degrees of morphological multifunctionality, which has complicated the task of identifying discrete functions for individual affixes. Certain combinations of prefix and suffix appear to function as circumfixes, while others appear to be genuinely morphologically complex. Moreover, several of these voice-valency morphemes exhibit complex relationships with aspect as well--which Malayic languages do not otherwise mark morphologically--blurring the boundaries of their roles and further evidencing high degrees of polysemy. The individual functions of these affixes, then, are notoriously hard to tease apart, and this task has proven challenging to researchers for decades.

Minangkabau, another Malayic language spoken in West Sumatra, shows much of the same complexity within its verbal system. Inheriting the same compact system of voice-valency marking, this language displays a high degree of structural similarity with Indonesian and Malayand it shares many of the same puzzles within its verbal system. Yet the complexity of this language's verbal morphology is compounded by the problem of under-documentation: while the

\footnotetext{
${ }^{*}$ We are grateful to Alief Moulana and the participants of LING 280 (Field Methods) in Spring 2016 at Carleton College, especially Joyce Domogalla. We also thank the audience at the 91st Annual Meeting of the Linguistic Society of America in Austin for their comments, questions, and discussion, especially Bradley McDonough, Stanley Dubinsky, Paul Kroeger, Jason Overfelt, Uri Tadmor, and Jozina Vander Klok. All errors are our responsibility. Authors: Daniel Brodkin, Carleton College (brodkind@ carleton.edu) \& Catherine Fortin, Carleton College (cfortin@carleton.edu).
} 
few existing grammars provide broad descriptions of its voice system, the verbal domain at large, and especially its valency-adjusting morphology, remain poorly described and understood.

The present study seeks to describe the functions of the Minangkabau $-i$, a productive suffix which displays a broad array of semantic functions.
a. Pamasak mang-asin-i ikan=ko.
cook ACT-salt-i fish=DEM
'The cook salted the fish.'
b. Aden mam-punyo-i buku.
1SG ACT.possession-i book
'I have a book.'
$\begin{array}{lll}\text { c. Inyo ma-lacuik-i } & \text { banta } \\ \text { 3SG } & \text { ACT-whip-i } & \text { pillow }\end{array}$
'He whipped the pillow over and over again.'
d. Ang=sipak-i=den
$2 \mathrm{SG}=\mathrm{kick}-\mathrm{i}=1 \mathrm{SG}$
'I was kicked by you.'

Previously published work contains no clear agreement about the meanings of this suffix in Minangkabau, and its Indonesian/Malay cognate $-i$ has not fared much better: the precise functions $-i$ are poorly understood in both of these languages. Thus, a careful investigation of the Minangkabau suffix has the potential to bring to light subtle grammatical differences between these languages and to inform our understanding of the applicative typology of Western Indonesia more broadly.

The rest of this paper is organized as follows: in section 2, we introduce the shared verbal system of Indonesian and Minangkabau, outlining the various functions of the voice- and valency-adjusting morphology common to these languages. In section 3, we offer a review of the literature on $-i$, then present our own analysis of its functions and distribution in section 4 . We summarize our findings and present further questions in section 5. All Minangkabau data, unless otherwise indicated, were collected from a 20-year-old native speaker of Minangkabau and Indonesian from Solok, West Sumatra.

2. Morphological background. Minangkabau and Indonesian have inherited a common set of voice- and valency-adjusting prefixes from Proto-Malayic, which will be discussed throughout this section. First, we will outline a regional typology of verbal systems in Western Indonesia in section 2.1, then present the morphological inventory of Minangkabau and Indonesian in 2.2, outlining the broad roles of each morpheme. We conclude in 2.3 with illustrations of certain combining forms.

2.1. WESTERN INDONESIAN VERBAL TYPOLOGY. Many languages spread throughout Western Indonesia display broad similarities in their verbal systems. Typologically, these languages show little verbal agreement in the traditional categories of tense, aspect, and mood (TAM), which are instead most often encoded through a set of stand-alone temporal/aspectual markers and modals.

Voice and valency, however, are robustly marked morphologically across the region. Many languages encode multiple types of voice distinctions through a rich system of prefixing morphology, typically construed to select "pivots" of different thematic roles. Similarly, many languages contain highly productive types of applicative morphology, licensing arguments like causers, benefactors, and locatives. 
2.2. VERBS IN INDONESIAN AND MINANGKABAU. Indonesian and Minangkabau fit neatly into this regional typology. While these languages lack overt TAM morphology, they both contain rich sets of TAM markers-- and within the domain of voice and valency, they contain a compact, powerful morphological toolkit, presented in Table 1.

\begin{tabular}{|c|c|c|}
\hline Gloss & Minangkabau & Indonesian \\
\hline ACT & $m a N-$ & $m e N-$ \\
\hline MID & $b a-$ & $b e r-$ \\
\hline PASS & $d i-$ & $d i-$ \\
\hline $\begin{array}{c}\text { INVOL } \\
\text { ABIL }\end{array}$ & $t a-$ & ter- \\
\hline APP & $-a n$ & $-k a n$ \\
\hline & $-i$ & $-i$ \\
\hline
\end{tabular}

Table 1: Verbal morphology in Minangkabau and Indonesian

These cognate affixes generally function similarly across the two languages, and, with the possible exception of $d i$ - 'PASS', are uncontroversially considered to be multifunctional. The precise function(s) of many of these affixes, most notably $m a N-/ m e N-$, are disputed; see e.g. Soh $\&$ Nomoto 2015 for a recent overview. For simplicity, we note here only the most canonical, and productive, meanings/functions for each affix. The glosses provided for each are descriptive, and do not presuppose any particular analysis. Among the voice prefixes, the agent-focus marker maN-/meN- ${ }^{1}$ 'ACT' surfaces in active, transitive clauses with SVO word order, while the patientfocus marker $d i$ - 'PASS' occurs in passive clauses with the orders VSO or OVS. (Verbs with no overt voice prefix appear in both active and passive clauses.) The prefix ba-/ber- 'MID' is found in middle constructions of various types, including reflexive and reciprocal constructions; forms stative verbs from transitive roots; and forms intransitive verbs from nominal and adjectival roots (Crouch 2009; Sneddon et al 2010). Finally, the prefix ta-/ter- 'INVOL' creates involuntary passives and abilitatives from verbs, and superlative predicates from adjectival roots (Crouch 2009; Sneddon et al 2010).

There are just two verbal suffixes, -an/-kan and $-i$, which play a multitude of roles in both languages. The first, -an/-kan 'APP' has a broadly applicative function, creating causatives, licensing benefactors, and often appearing on ditransitive verbs and in imperatives. The latter, $-i$, the focus of this paper, is often typically assumed to fundamentally be an applicative as well. Although the better-studied -an/-kan is perhaps perceived to surface more frequently on verbs, as we will argue, $-i$ has a broad distribution in its own right, and displays four distinct functions, only two of which involve increasing valency.

Indonesian and Malay display a significant cross-dialectal variation in the functionality of this morphology. Certain regional dialects, like Papuan Malay, have lost particular prefixes and

\footnotetext{
${ }^{1}$ When two forms are listed side by side in this manner, the form on the left is Minangkabau and the form on the right is Indonesian, unless otherwise indicated.
} 
suffixes wholesale (Kluge 2014), while others, like Jakarta Malay, have merged both of the applicatives into a single suffix -in. Furthermore, some regional dialects have gone so far as to wholly reinterpret the etymological agent-focus and patient-focus prefixes $m e N$ - and $d i$ - as aspectual markers (Cole, Hermon, \& Yanti 2008). Thus, even inside individual languages, these affixes have often developed strikingly divergent roles.

3. Existing treatments of $-i$. Both Minangkabau $-i$ and Indonesian $-i$ are less well-described in the existing literature than some other aspects of the verbal morphology of these languages, including -an/-kan, which has some superficially similar functions. Indonesian $-i$ is somewhat better described than Minangkabau $-i$, although for both, there is a lack of consistency in the existing literature.

Previous accounts of Minangkabau $-i$ can be found in Adnani 1971, Crouch 2009, Moussay 1998, Reibaud 2004, and Williams 1961. Crouch, who offers the most recent in-depth description of Minangkabau verbal morphology, identifies $-i$ as a 'locative applicative... which interacts with the Minangkabau voice system in a similar way to -an' (2009: 179-180). Under Crouch's analysis, both $-i$ and $-a n$ have complementary valency-increasing functions; $-i$ specifically promotes locative adjuncts, while -an is an applicative licensing undergoers, recipients, and benefactives.

(2) Inyo ma-ranang-i lawik.

3SG ACT-swim-APP:LOC sea

'He swam across the ocean.' (Crouch 2009: 180)

Other previous work, including Adnani 1971, Moussay 1998, Reibaud 2004, and Williams 1961, recognizes a function akin to that which Crouch describes, as licensing a locative argument.

With the exception of Crouch 2009, the previous work also collectively observes that there is an iterative function of $-i$, citing examples such as makan 'eat' and makan-i 'eat up' (Adnani 1971: 53); lacuik 'whip' and lacuik-i 'whip a lot' (Reibaud 2004: 79). Again with the exception of Crouch 2009, the previous work identifies a 'causative' function.

(3) Kato=tu man-jirah-i talingo.

word=DEM ACT-red $-i$ ear

'Those are harsh words. (lit.:Those words cause the ears to be red.)' (Adnani 1971: 135)

These four works, however, reveal less common ground regarding $-i$ 's other functions. Adnani (1971: 131) identifies an $-i$ which attaches to nominal bases and creates a form 'signify[ing] a two-place action meaning "to give, to provide, or to supply... with the nominal specified by the base'. Adnani further shows that this $-i$ is able to co-occur with a variety of prefixes, including abilitative $t a$-, involuntary $t a-$, and stative $b a$ -
a. Si Djanar ma-abu-i sawah.
Djanar ACT-ash-i rice.field
'Si Djanar put ashes on the rice field.' (Adnani 1971: 131-2)
b. Sawah di-abu-i Si Djanar.
rice.field PASS-ash-i Djanar
'The rice field was fertilized with ash by Djanar.' (Adnani 1971: 132) 


\section{c. Sawah ta-abu-i dek Si Djanar. rice.field ABIL-ash-i by Djanar}

'Djanar is capable of fertilizing the rice field with ashes.' (Adnani 1971: 132)

Moussay 1998 identifies a possibly similar 'transitive/locative' use of $-i$, which creates verbs such as atoki 'put a roof on' from bases such as atok 'roof'. Reibaud (2004: 70-71), on the other hand, identifies separate 'locative' and 'transitive' functions. The latter function creates forms such as mambului 'to defeather' from bulu 'feather'. ${ }^{2}$

Previous accounts of Indonesian - $i$ appear in Dardjowidjojo 1971, Vamarasi 1999, and Sneddon et al 2010; each analysis partially overlaps with the others, but no two are identical. Sneddon et al 2010 identifies 'two major functions' for Indonesian $-i$ : $-i$ which indicates that the object is the location of the action (not dissimilar to Crouch's analysis for Minangkabau - $i$ ), and $i$ which indicates repeated action or thoroughness, akin to the iterative $-i$ discussed above. Vamarasi 1999, in contrast, identifies three kinds of $-i$ in Indonesian. The first two recall functions previously discussed, $-i$ adding a locative object, and $-i$ on adjectival, nominal, and intransitive verbal bases (e.g. memarahi 'be angry at' from marah 'angry' and mengobati 'give medicine' from obat 'medicine'). The third type, the $-i$ found on ditransitive verbal roots which triggers an alternation between DP/PP and a double object construction, appears to be novel. Vamarasi glosses this $-i$ 'IO', for promotion of the PP to indirect object.

a. Isak mengajar ilmu bumi pada murid-murid.

Isak ACT-teach science earth to student-REDUP

'Isak teaches geography to the students.'

b. Isak meng-ajar-i murid-murid ilmu bumi.

Isak ACT-teach-IO student-REDUP science earth

'Isak teaches the students geography.' (Vamarasi 1999: 78)

Dardjowidjojo's (1971) analysis, meanwhile, distinguishes 'obligatory' $-i$, which attaches to 'mostly nominal and adjectival bases' from 'optional' $-i$, which is found on some intransitive and monotransitive verbs, and which subsumes both the locative and iterative functions of $-i$. Dardjowidjojo, like Crouch, largely discusses optional $-i$ only in comparison to -kan, summarizing, 'If the... base verb is monotransitive, the -kan and $-i$ contrast can be of two kinds.... while the $-k a n$ is always benefactive or directive, the $-i$ verb can be repetitive... and $-i$ can be locative' (Dardjowidjojo 1971: 79-80).

It is not clear whether discrepancies in descriptions such as these follow from dialectal or individual differences, from incomplete documentation, from differing terminology, from differing interpretations of the data, or from some combination thereof. We don't know why, for example, neither Crouch 2009 nor Vamarasi 1999 note the iterative function of $-i$ that the other works do. Even from these varied descriptions, however, it is clear that we can expect to see at least some overlap between Indonesian $-i$ and Minangkabau $-i$. It is also misleading to characterize $-i$ as an applicative, as not all of its ascribed functions involve increasing valency. In the next section, in an attempt to resolve some of these discrepancies, we offer a description of $-i$ based on data collected from our own native speaker consultant. Although the expected overlap with Indonesian $-i$ is realized, there remain some differences in behavior, which are discussed in 4.5 ; these involve the co-occurrence of $-i$ with particular verbal prefixes and the raising

\footnotetext{
${ }^{2}$ Additionally, Williams 1961 classifies $-i$ as a 'stem formative', in contrast to 'external prefixes' such as $m a N$-. The nature of the distinction is not entirely clear.
} 
possibilities $-i$ allows when suffixed to passives Our analysis further diverges from previous literature in recognizing an adversative interpretation for $-i$, which has, to our knowledge, never surfaced in any previous accounts of Minangkabau and is notably absent in Indonesian.

4. Four functions of $\boldsymbol{- i}$. We propose that Minangkabau $-i$ has four distinct, productive functions.

(6) Functions of Minangkabau $-i$

a. license a locative object (1a)

b. form transitive verbs from non-verbal bases (1b)

c . mark iterative, repetitive, or intensive aspect (1c)

d. impute an adversative interpretation on verbs (1d)

In the following sections, we delineate the functionality of Minangkabau $-i$, starting with evidence for each distinct role we identify in subsections 4.1-4.4. Next, we turn towards its distribution in section 4.5, showing that it may combine freely with the non-volitional prefix $t a$ (cf Indonesian ter-), which its Indonesian counterpart may not do (Sneddon et al 2010). Lastly, in section 4.6, we discuss the raising possibilities which passive verbs admit when suffixed with $-i$ and illustrate another clear contrast between this morpheme and its Indonesian cognate.

4.1. LOCATIVE -I. The canonical function of $-i$ (i.e., the function most frequently remarked upon in the literature) appears to be licensing locative objects, for three different types of bases. Many intransitive verbs can take locative objects when suffixed with this morpheme.

(7) a. Elliot datang ka rumah=den

Elliot come to house $=1 \mathrm{SG}$

'Elliot came to my house.'

b. Elliot datang-i=den

Elliot come-i $=1 \mathrm{SG}$

'Elliot visited me.'

Similarly, locative $-i$ licenses locative objects on transitive verbs.

(8) a. Inyo man-[t]ulih buku.

3SG ACT-write book

'She wrote a book.'

b. Inyo man-[t]ulih-i buku namo=nyo.

3SG ACT-write-i book name $=3 \mathrm{SG}$

'She wrote her name on a book.'

The range of bases which productively take this $-i$ is large, as shown in Table 2. 


\begin{tabular}{|c|c|c|c|}
\hline Verb & Gloss & $-\boldsymbol{i}$ - form & Gloss \\
\hline duduak & 'sit' & duduaki & 'sit on, occupy' \\
\hline tabang & 'fly' & tabangi & 'fly over' \\
\hline jalan & 'walk' & jalani & 'walk on, experience' \\
\hline lompek & 'jump' & lompeki & 'jump over' \\
\hline ujan & 'rain' & ujani & 'rain on' \\
\hline karajo & 'work' & karajoi & 'prank' \\
\hline muek & 'contain' & mueki & 'load with' \\
\hline lihek & 'see' & liheki & 'look after' \\
\hline buang & 'throw' & buangi & 'throw into' \\
\hline pacayo & 'believe' & pacayoi & 'entrust' \\
\hline twit & 'tweet' & twiti & 'tweet at' \\
\hline
\end{tabular}

Table 2: Locative $-i$ in Minangkabau

Lastly, locative $-i$ on ditransitive verbs licenses an immediately postverbal direct object. This is the third type of Indonesian - $i$ proposed by Vamarasi as a separate category; we return to these data in 4.6 to justify our departure from her analysis.

(9) Inyo mang-[k-]irim-i=den surek

$3 \mathrm{SG}$ ACT-send-i=1SG letter

'She sent me a letter.'

Departing, now, from Adnani 1971, Moussay 1998, Reibaud 2004, and Williams 1961, we do not ascribe to $-i$ a distinct 'causative' function. We choose instead to group it under the locative based on key semantic contrasts with the causative morpheme -an. Many verbs previously identified with the causative $-i$ are, we believe, better grouped under this locative function. While certain 'causatives' identified in the literature were straightforwardly rejected by our consultant, others can be shown to clearly contrast with a true causative: verbs with $-i$ take a clearly locative reading when compared to causative forms with -an. For example, asini, from the nominal root asin 'salt', is interpreted as 'to salt (by putting salt on)', while asinan is interpreted as 'to salt (by brining)'; in other words, there is a contrast between applying salt to another object, encoded by asini, and applying the object to a salty solution, encoded by asinan.
a. Pamasak mang-asin-i ikan=ko. cook ACT-salt-i fish=DEM
'The cook salted the fish.'
b. Pamasak mang-asin-an ikan=ko cook ACT-salt-AN fish=DEM
'The cook salted the fish.'

The same analysis also pertains to certain adjectival verbs with $-i$ previously identified as causatives, as serahi 'to redden', from serah 'red'.

Contrasts of this type are robust in Minangkabau: verbs which show spray/load alternations frequently occur as $-i$-an doublets, where the form with $-i$ selects the locative as the core argument. Doublets of this type clearly illustrate the locative meaning of this suffix. 
Consider, for example, the root muek, 'to contain': while the interpretation of muekan is 'to load $\mathrm{X}$ into $\mathrm{Y}$ ', the interpretation of mueki is 'to load Y with $\mathrm{X}$ '.

(11) a. Kapa ma-muek bareh. ship ACT-contain rice

'The ship contains rice.'

b. Inyo ma-muek-an bareh ka kapa.

3 ACT-load-AN rice to ship

'They loaded rice into the ship.'

c. Inyo ma-muek-i kapa jo bareh.

3 ACT-load-i ship with rice

'They loaded the ship with rice.'

4.2. TRAnsitivizING $-I$. The second type of $-i$, 'transitivizing $-i$, , serves to create transitive verbs from nominal roots. A further list is provided in Table 3.
a. Kami ba-caka.
1PL.EXCL MID-fight
'We're having a fight.'

b. Aden caka-i siapun nan makan ayam=den

1SG fight-i whoever REL eat chicken=1SG

'I will fight whoever ate my chicken.'

\begin{tabular}{|c|c|c|c|}
\hline Root & Gloss & $\mathbf{- i \text { - form }}$ & Gloss \\
\hline punyo & 'possession' & punyoi & 'have' \\
\hline masuk & 'entrance' & masuaki & 'enter' \\
\hline salamek & 'congratulations' & salameki & 'congratulate' \\
\hline
\end{tabular}

Table 3: Transitivizing $-i$ in Minangkabau

Additionally, certain roots (e.g. suko 'like') optionally bear $-i$ when taking a DP complement, but not when taking a clausal complement.

a. Aden suko/ many-[s]uko-i cubadak.

1SG like/ ACT-like- $i$ jackfruit

'I like jackfruit.'

b. Uda suko/ *many-[s]uko-i makan cubadak.

brother like/ *ACT-like- $i$ eat jackfruit

'Brother likes to eat jackfruit.'

Speakers have clear and consistent judgments about the pattern illustrated above: with a DP complement, a root such as suko 'like' can appear in either its bare form or with an $-i$ suffix, and there is no difference in interpretation between the two. (Specifically, this $-i$ does not impute an iterative or intensive interpretation. Our consultant, however, does note that a form such as manyukoi is 'more formal' than suko, and perhaps even has a 'poetic' quality.) When suko is an embedding predicate, in contrast, $-i$ is not permitted to appear. This differential behavior may suggest that $i$ has, or once had, the ability to check Case, although $-i$ is no longer necessary to check the Case of a DP direct object: the predicate itself can now do so. Since the $-i$ forms of these predicates are incompatible with clausal complements, however, we tentatively propose that the case-licensing functions of $-i$ remain syntactically relevant. 
4.3. ITERATIVE $-I$. With certain verbs, the suffixation of $-i$ creates an iterative, repetitive, or intensive reading. As noted above, this type of $-i$ is addressed in most previous literature on $-i$, with the exception of Crouch 2009 for Minangkabau and Vamarasi 1999 for Indonesian. Despite this omission, this aspectual interpretation appears to be fairly productive; a further list is provided in Table 4.
a. Ambo mam-bali arato waang. 1SG ACT-buy wealth $2 \mathrm{SG}$
'I bought your wealth.'
b. Ambo mambali-i arato waang.
$1 \mathrm{SG} \quad$ ACT-buy-i wealth $2 \mathrm{SG}$
'I bought up your wealth.'

\begin{tabular}{|c|c|c|c|}
\hline Root & Gloss & $-\boldsymbol{i}$ - form & Gloss \\
\hline cium & 'kiss' & ciumi & 'kiss repeatedly' \\
\hline lacuik & 'whip' & lacuiki & 'whip intensely' \\
\hline makan & 'eat' & makani & 'eat up' \\
\hline tanya & 'ask' & tanyai & 'interrogate' \\
\hline jago & 'guard' & jagoi & 'take care of' \\
\hline
\end{tabular}

Table 4: Iterative $-i$ in Minangkabau

4.4. AdVERSATIVE $-I$. A number of verbs take the suffix $-i$ to create an adversative form. If the verb is bare, this $-i$ appears to require encliticized agent and theme pronouns.
a. Ang=sipak-i=den.
$2 \mathrm{SG}=$ kick-i $1 \mathrm{SG}$
'I got kicked by you.'
b. Nyo=liek-i=den.
$3 \mathrm{SG}=$ see- $\mathrm{i}=1 \mathrm{SG}$
'Someone was stalking me.' (lit: 'I got seen by someone.')

In contrast to the three functions of $-i$ already discussed, this construction has limited productivity. The obligatory subject-object encliticization which it requires further sets it apart from all the other functions of this suffix (and, to the best of our knowledge, all other verbal forms in Minangkabau): we know of know other verbal constructions that show any such requirement. Diachronically, this function may derive from - or represent - the aspectual role of $-i$, as these constructions seem to imply a clear sense of intensive, conscious repetition, with malicious intent.

These constructions contrast with the typical Minangkabau adversative along precisely this semantic axis. Normal adversatives, formed with the circumfix ke-an, typically take nonvolitional subjects. However, this adversative- $i$ construction appears to directly emphasize the volitionality of the agent. Our consultant reports that the extent of the agent's intentionality is what distinguishes these constructions, a departure from other adversatives in this language.
a. Aden
ka-racun-an
gulo-gulo
basi
$1 \mathrm{SG}$
ADV-poison-ADV sugar-REDUP
spoiled
'I got poisoned by spoiled candy.' 
b. Aden di-racun-i=nyo.

$1 \mathrm{SG} \quad$ PASS-poison-i=3SG

'I got poisoned by him.'

4.5. DistRIBUTIONAL FACTORS. Minangkabau $-i$ readily combines with all four voice-marking prefixes, unlike its better-known counterpart in Indonesian. Forms with $\mathrm{maN}$ - 'ACT' and $d i$ 'PASS' are seen in the examples above. This morpheme may also occur with the prefix $b a$ - 'MID', contrasting in this example with $d i-$, as Adnani (1971) observed.
a. Jalan di-jalan-i.
road PASS-walk-i
'The road is being walked.'
b. Iduik ba-jalan-i.
life MID-walk-i
'Life is being experienced.'

Notably, contrasts emerge with the non-volitional morpheme $t a$-, cognate to the Indonesian ter-. As noted above, this prefix has several functions, and two are of interest here: creating 'accidental passives', where the role of the agent is de-emphasized, and creating abilitative predicates.
a. Aden ta-dangan.
1SG INVOL-hear
'I accidentally got heard.'
b. Bintang=tu ta-liek dek inyo.
stars=DEM INVOL-see by $3 \mathrm{SG}$
'The stars can be seen by him.'

Sneddon et al (2010:120) remark that for many speakers, in Indonesian, accidental ter-cannot combine with the suffix $-i$. For example, pengaruhi 'influence, affect' loses its $-i$ when it combines with accidental ter-.

(19) Penduduk se-tempat tidak akan ter-pengaruh(*-i) oleh rencana pemerintah. population ONE-place NEG FUT INVOL-affect(*-i) by plan government 119)

'The local population won't be affected by the government's plan.' (Sneddon et al 2010:

In Minangkabau, in contrast, both accidental and abilitative ter- readily co-occur with $-i$. Although Adnani 1971 observes that abilitative ter- co-occurs with $-i$, he does not address the combination of accidental ter - and $-i$.

a. Ambo ma-luko-i kaki=nyo.

1SG ACT-wound-i foot=3SG

'I wounded his foot.'

b. Kaki=nyo ta-luko-i ambo.

foot=3SG INVOL-wound-i $1 \mathrm{SG}$

'His foot was accidentally wounded by me.'

(21) a. Aden mam-palajar-i buku.

1SG ACT.study-i book

'I study the book.' 
b. Buku=tu ta-palajar-i dek inyo. book=DEM ABIL-study-i by 3 SG

'This book can be studied by him (because he is very smart).'

Minangkabau $-i$ shows a second distributional difference from its Indonesian counterpart: the latter is unable to be suffixed to verbal stems ending in /i/ (Sneddon et al 2010: 89), but no such restriction applies in Minangkabau, as seen in (14b), and as reported by Williams 1961 and Adnani 1971.

4.6. PASSIVES AND RAISING WITH $-I$. Minangkabau $-i$ shows a significant syntactic difference with its cognate Indonesian suffix in passive constructions, where ditransitive verbs suffixed with $-i$ allow both theme and goal arguments to raise to subject position.
a. Inyo mang-[k-]irim-i=den surek.
$3 \mathrm{SG}$ ACT-send-i=1SG letter
'She sent me a letter.'
b. Aden dikirim-i surek dek=nyo
$1 \mathrm{SG}$ PASS-send-i letter by=3SG
'I was sent a letter by him.'
c. Surek=tu di-kirim-i=nyo ka=den. letter=DEM PASS-send- $\mathrm{i}=3 \mathrm{SG}$ to $=1 \mathrm{SG}$
'A letter was sent by him to me.'

In Indonesian, however, only goal arguments of ditransitive - $i$-verbs may raise to subject position in passives (Chung 1976).

(23) a. Laki-laki itu meng-[k]irim-i wanita itu sepujuk surat.
man DEM ACT-send-i woman DEM a letter
'The man sent the woman a letter.' (Chung 1976: 55)
b. Wanita itu di-kirim-i sebuah surat oleh laki-laki itu.
Woman DEM PASS-send-i a letter by man DEM
'The woman was sent a letter by the man.' (Chung 1976: 58)
c. * Surat itu di-kirim-i wanita itu.
letter DEM PASS-send-i woman DEM
('The letter was sent the woman.' (Chung 1976: 61))

Given this difference in behavior, Vamarasi's claim that Indonesian has a distinct $-i$ that appears on ditransitive verbs is not well-motivated for Minangkabau.

Section 5. Conclusions. In this paper, we have argued that there are four distinct functions for the Minangkabau suffix $-i$ - licensing locative arguments, transitivizing nominal bases, marking iterative, repetitive, or intensive aspect, and creating a certain type of adversative construction indicating this morpheme to be broader in both function and distribution than its Indonesian counterpart. We do not ascribe to this morpheme an exclusively causative function, such as that previously identified in the literature, showing that apparent instances of this meaning are better grouped under the locative role of the suffix. Furthermore, we note two syntactic differences between the Minangkabau $-i$ and its Indonesian counterpart: the former may combine with the accidental ter- prefix and bases ending in /i/, while the latter may not. Similarly, the Minangkabau suffix allows for both goal and theme arguments to raise in passives, while Indonesian $-i$ only permits goal-raising. The comprehensive analysis of this morpheme which we 
provide sheds light on patterns of polysemy in verbal morphology in Indonesian and related languages, and is of typological interest more broadly.

Moving forward, this research opens up many new avenues for investigation into the nature of Minangkabau applicatives. The adversative function which we identify, previously unmentioned in the literature, prompts a number of phonological, syntactic, and lexical questions: what types of bases can take this role when combined with $-i$ ? Can non-pronominal arguments- or pronouns unable to encliticize- occur in this construction? What syntactically motivates these restrictions, and how do these arguments behave with respect to traditional tests of subject- and object-hood?

Beyond this construction, this survey poses a set of typological questions about the semantic ranges of applicative morphology more broadly. The overlapping functions displayed by $-i$ may highlight a semantic unity between transitivizers and markers of particular types of aspect. In the same vein, if these functions of $-i$ should be attributed to a single unitary morpheme, larger questions surface about how the predicate's pre-existing argument structure might condition the meanings $-i$ introduces.

\section{References}

Adnani, Dahnil. 1971. Minangkabau sentences and their constituents: an exploration in semantically based grammatical analysis. Washington, DC: Georgetown University dissertation.

Chung, Sandra. 1976. An object-creating rule in Bahasa Indonesia. Linguistic Inquiry 7.1: 41-87.

Cole, Peter, Gabriella Hermon, \& Yanti. 2008. Voice in Malay/Indonesian. Lingua 118: 15001553.

Crouch, Sophie E. 2009. Voice and verb morphology in Minangkabau, a language of West Sumatra, Indonesia. Perth: University of Western Australia thesis.

Dardjowidjojo, Soenjono. 1978. Sentence patterns of Indonesian. Honolulu: University Press of Hawaii.

Kluge, Angela J.H. 2014. A grammar of Papuan Malay. Leiden: University of Leiden dissertation.

Moussay, Gerard. 1998. Tata bahasa Minangkabau. Jakarta: Kepustakaan Populer Gramedia.

Reibaud, Rusmidar. 2004. Parlons Minangkabau. Paris: L'Harmattan.

Sneddon, James N., Alexander Adelaar, Dwi N. Djenar, \& Michael C. Ewing. 2010. Indonesian: a comprehensive grammar. Second edition. London and New York: Routledge.

Soh, Hooi Ling \& Hiroki Nomoto. 2015. Degree achievements, telicity, and the verbal prefix meN- in Malay. Journal of Linguistics 51.1: 147-183.

Son, Minjeong \& Peter Cole. 2008. An event-based account of -kan constructions in Indonesian. Language 84: 120-160.

Vamarasi, Marit Kana. 1999. Grammatical relations in Bahasa Indonesia. Canberra: Pacific Linguistics.

Williams, Gerald E. 1961. Colloquial Minangkabau: a description of phonological and morphological structure. Chicago: University of Chicago dissertation. 